\title{
MINING ACTIVITY AND ITS REMAINS - THE POSSIBILITIES OF OBTAINING, ANALYSING AND DISSEMINATING OF VARIOUS DATA ON THE EXAMPLE OF MIEDZIANKA, LOWER SILESIA, POLAND
}

\author{
R. Kawiecka a, , A. Krawczyk a , P. Lewińska a ${ }^{\text {a }}$ K. Pargieła a , Stanisław Szombara a *, \\ A. Tama ${ }^{\text {a }}$, K. Adamek ${ }^{\text {, }}$, M. Lupa ${ }^{\text {b }}$ \\ ${ }^{\text {a }}$ AGH University of Science and Technology, Faculty of Mining Surveying and Environmental Engineering, A. Mickiewicza Av. \\ 30, 30-059 Cracow, Poland, e-mail: szombara@agh.edu.pl \\ ${ }^{\mathrm{b}}$ AGH University of Science and Technology, Faculty of Geology, Geophysics and Environmental Protection, A. Mickiewicza Av. \\ 30, 30-059 Cracow, Poland
}

Received: 14.10.2018 / Accepted: 12.11.2018/ Revised: 20.11.2018 / Available online: 15.12.2018

DOI: 10.2478/jaes-2018-0020

KEY WORDS: GIS, mining areas, web application, photogrammetry.

\begin{abstract}
:
The article presents comprehensive documentation of the situation of post-mining Miedzianka village (former town), which is located in Lower Silesia, in south-western Poland. Due to the long-term expansive mining exploitation since the $14^{\text {th }}$ century, over time Miedzianka was completely destroyed and depopulated, thus nowadays, only a few inhabitants live there. The basis for the conducted research area were changes in land and urban structure that have been occurring for centuries in connection with mining operation of copper and uranium. The authors focused on presenting the changes using archival cartographic documentation, land surveying measurements and 3D modelling. That data allowed to determine on the ground specific sites related to mining operations, discover old urban buildings, performing their 3D models and finding places potentially threatened by continuous and discontinuous deformations. The combination of all the data allowed to present the full situation that occurred in Miedzianka.
\end{abstract}

\section{INTRODUCTION}

Preserving and sharing information about past mining events is a significant task due to importance of education, safety reasons and many others. Miedzianka has rich history of mining and is slowly repopulating again (bdl.stat.gov.pl). However, inhabitants are slowly destroying evidence and aftermaths of mining activities. Many of spoil tips are gradually disappearing due to anthropogenic denudation processes also remains of mining shafts being filled up and covered by layers of soil and eventually plant life. Thus, their placement is being forgotten. As both of mentioned objects can be dangerous for inhabitants due to pollution and collapsing risk, preserving information about them is an important task.

Data on location of old mining shafts, adits and drifts can be considered as geographic information (Gomarasca, 2009). Geographic Information System (GIS) fully fits as a tool that could be used to process and share information about Miedzianka with any interested party. Recently, geographic information (GI) along with GIS is extensively used to describe and explain many topics and patterns (Longley et al., 2001). That data can be made available to wide range of users by with solutions like ArcGIS Online (AGOL), which is, according to (doc.arcgis.com) a "cloud-based mapping and analysis solution". AGOL can be used to visualize and share data through web app (doc.arcgis.com) that was used in this project. Data collected to track changes in Miedzianka over the centuries as well as results of its analysis are currently visualised online in a WebGIS application along with data collected by project members. The field research was carried out as part of the Rector's AGH-UST Grant "Construction of an information system for permanent monitoring of land deformation caused by historical mining in Miedzianka in Lower Silesia with the use of satellite radar interferometry". In the previous stages of the research, office work was carried out with the main focus on the analysis of cartographic materials regarding land use changes and INSAR data analysis (Tama et al., 2018). Recently, similar solutions aimed at providing access to the historical data using GIS tools can be found more and more easily. Popularity of this solution might be caused by possibility of presenting vast amount of data clearly. One of the examples is a project in which data on mining industry for the state of Maryland is shared (DeBruin et al., 2005). A geoportal was also used by (Olejnik, 2015) to share various data on postmining area of Wałbrzych Coal Basin. Those solutions show both the need to share this type of data and the rightness of use GIS for this purpose.

Since Poland joined the European Union in 2004, real-estate marked has been blooming. Capitals of all new member countries of the EU are undergoing large growth in investments in residential areas. With time this process spread to smaller towns and now even villages. Even during the financial crisis in 2008 in both Poland and in Romania a constant growth in realestate prices was observed (Mancia et al., 2017). However, this universal process did not include Miedzianka village. 
This is most probably due to the potential danger of building houses in the vicinity of mines that were not properly secured and lack of up to date information on ground stability and potential radioactivity of the area.

\section{RESEARCH AREA}

Miedzianka is a village (former town) located in Lower Silesia Province, Poland (Figure 1). Formerly, as a German town named Kupferberg it was considered to be one of the most beautiful towns in the region. Establishment of the town is dated to the $12^{\text {th }}-14^{\text {th }}$ century, with the first mentions of the mining activity from the $14^{\text {th }}$ century (Staffa, 1988; Madziarz, 2010; Makuch et al., 2013). Due to the rich deposits of many minerals (e.g., hematite, pyrite, magnetite, gold) and ores (mainly copper, arsenic, manganese and uranium) mining activity has been intensified over the centuries, focusing on copper and iron minerals. (Staffa, 1998; Zimnoch, 1978).
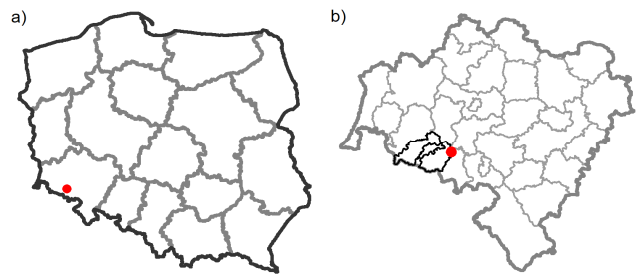

Figure 1. Location of the research area a) among all provinces, b) in the Lower Silesia province, black color stands for Jelenia Góra County

Last mining operations at Miedzianka happened after World War II, with works focused on excavating uranium ore. Between 1945-1956 years, excavation was carried with the aim of extracting as much uranium as possible, and contributed to the gradual destruction of the town due to the lack of proper excavation safety measures. (Madziarz, 2009, 2010; Springer, 2011). Majority of the buildings were destroyed and residents were resettled due to ensuing damage caused by aggressive mining policy. (Springer, 2011). Negative effects of mining exploitation were a factor for the city's desolation (Szmytkie et al., 2015).

\section{ACQUISITION AND ANALYSIS OF CARTOGRAPHIC MATERIALS}

\subsection{Acquisition and analysis of topographic data from} Miedzianka area

The first stage of the work was the acquisition, analysis and processing of archival topographic materials. Those were: resources from official georeferenced databases, scans of topographic and thematic maps, and terrain models from largescale photogrammetric surveys.

From the County Centre for Geodetic and Cartographic Documentation (pol. PODGiK), a modern cadastral map was acquired, as well as archival maps from the process of establishing land and building registration after the Second World War (Figure 2). The 1:5,000 scale map provided by PODGiK "Miedzianka map EG with the assumption of land registry" was made in 1952 by Jerzy Kopras, a surveyor of the Provincial National Council. It was completed in 1958 by Józefa Steker. The map was accepted into the state geodetic and cartographic resource (pol. PZGiK) in 1963. The map presents a standard content at that time. The main objects on the map include land parcels, land use classes and buildings. It should be noted that this map does not contain any information about projection used and elements allowing to give a georeference using the coordinates read from it. The topographic objects were used in the georeferencing process. The next map provided by PODGIK was the "cadastral map". This is a two-sheet development on a scale of 1:2,500. The description on the map shows that it was made in 1958 on the basis of the 1952 map described above. The map contains information that "the original is mapped on the basis of a map from 1863", which would indicate that the map editors had archival German materials at their disposal. In addition, we also find information that the map was made in 1946 from the original.
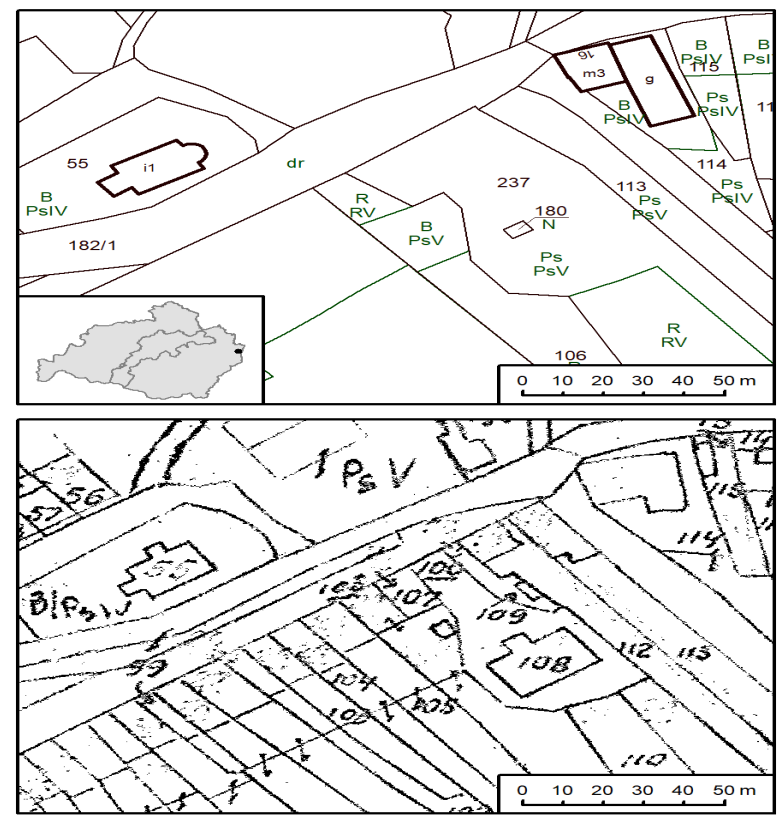

Figure 2. A fragment of a modern cadastral map (on the top) and an archive map from 1958 (on the bottom). In the left-hand corner, the location of fragments in the Jelenia Gora County is marked. Both maps show the centre of Miedzianka

The map was adopted by PZGIK in 1958. The content of the map does not differ from the standard cadastral map, except that it has additionally marked boundary points and other survey points. One can also see changes in the numbering of plots, which would indicate its subsequent intensive use (Figure 3).

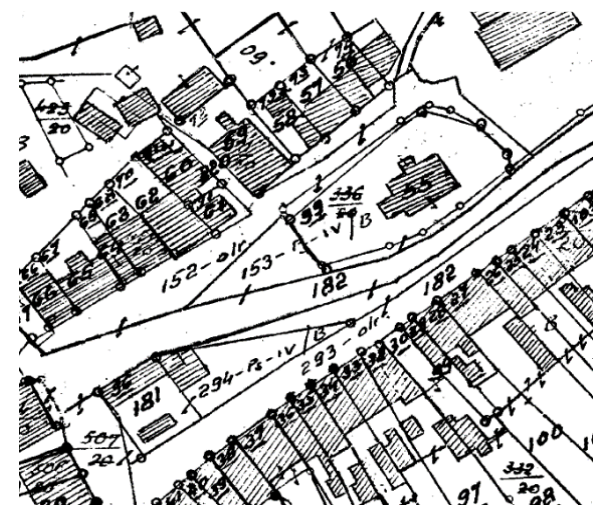

Figure 3. Fragment of a „cadastral map” in scale 1: 2,500 from 1958 

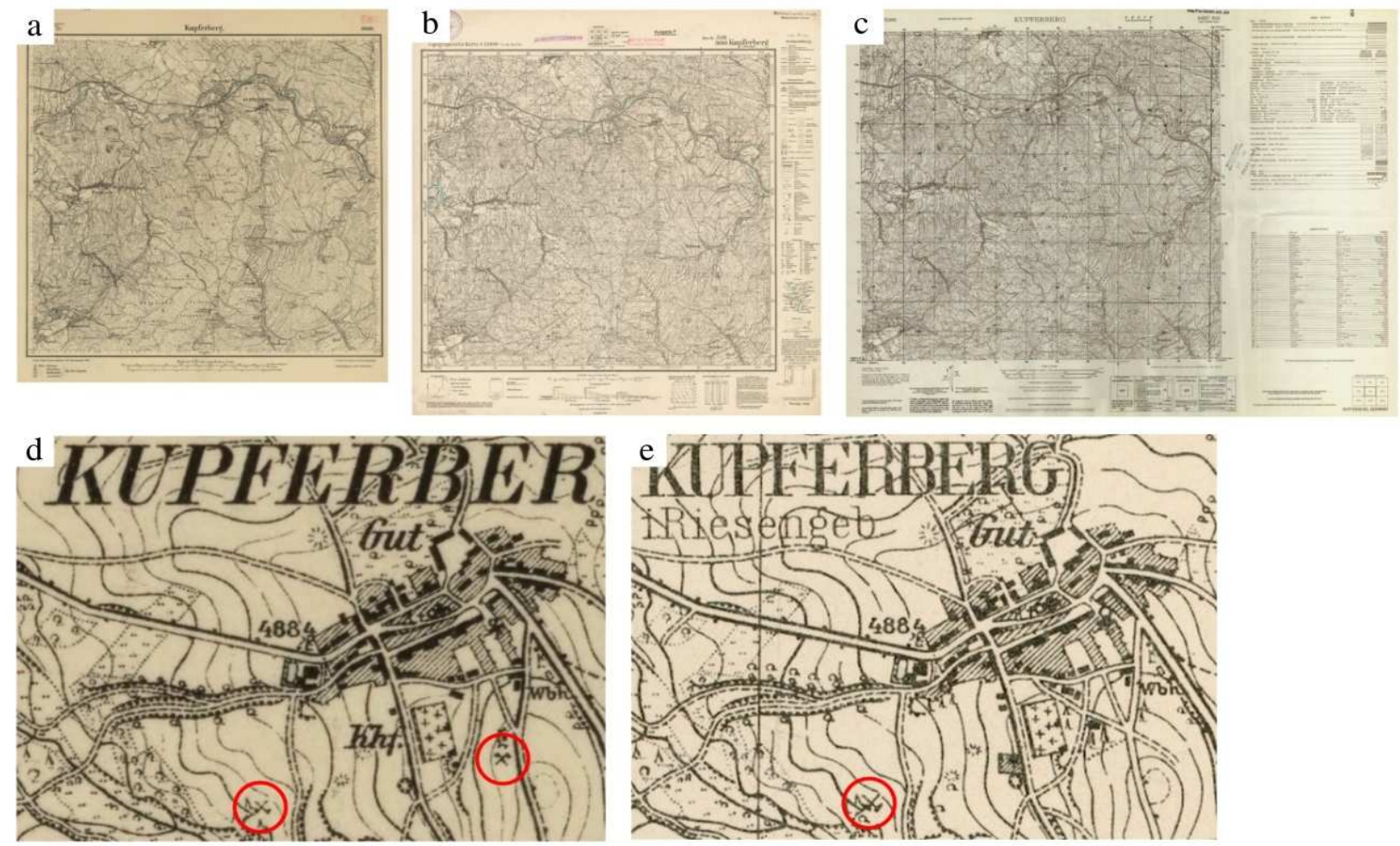

Figure 4. German topographic maps 1: 25,000: a) from 1886 b) from 1939 c) American map based on German from 1953 d) enlarged map "a)" e) enlarged map "b)". The active and closed mining shafts were marked on the enlargements.

A large part of archival materials that were analysed were topographic maps acquired primarily from the Archive of WIG maps (polski.mapywig.org). All maps are currently in the public domain and can be found in the resources of other digital libraries. Three archival topographic maps were selected for further study. These were topographic maps 1: 25000 Kupfenberg from 1886, 1939 and 1953. All three were issued in the same sheet cut. The first publisher was KöniglichPreussische Landesaufnahme, the second Reichsamt für Landesaufnahme, and the third - Army Map Service. The last map is an American map developed on the basis of German topographic materials from 1939 and is enriched with UTM mesh and descriptions.

On all three maps, the content of the built-up areas (or individual buildings) was marked (and there function indicated). Also active or closed mining shafts were marked. It was also very helpful that the maps presented roads and hydrographic network (Figure 4). All the above-mentioned maps were georeferenced based on topographic objects.

In Figure $4 \mathrm{~d}$ ) on the map from 1886 two mining shafts were marked: one closed and the other one open. On Figure 4 e) from 1939 it can be seen that the mine shaft was in 1886 closed and liquidated, while the shaft which in 1886 was still closed in 1939, remained closed. During the period of uranium exploitation after 1948, this shaft was opened and carried the designation of shaft no. 3 , and it served three mining levels.

Another cartographic material that was used was the 1: 10,000 scale Polish topographic map 'Janowice Wielkie' (emblem 462.31). The sheet used in the work was published in 1983 (Figure 5). The map was made in the PWUG 1965 projection (EPSG: 2174), which allowed to give it a georeference based on grid lines. In relation to the German maps, there are clearly visible changes in built-up areas in the centre of Miedzianka as well as a large amount of intermediate remains of the mining industry. No closed shafts are marked, but one can find a large number of heaps and pits that cannot be represented in scale. On this map, there are no built-up areas, only single buildings in the centre of Miedzianka.

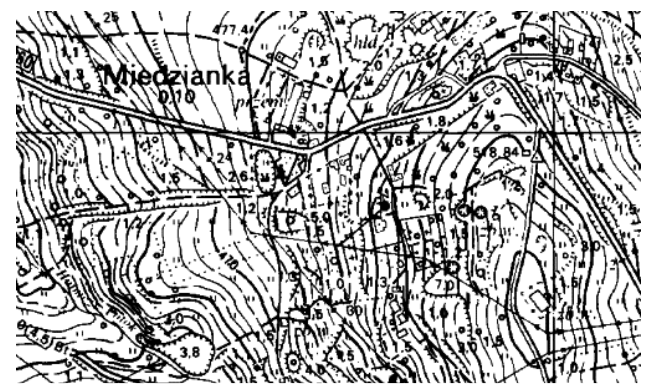

Figure 5. Polish topographic map in scale 1: 10,000

No mining shaft is marked on this map, which allows to state that all mining shafts have been closed before 1983. In the context of the topographic map, the closing of the shaft actually means the dismantling of the shaft tower or the closure of the shaft or adit entrance. However, previously closed shafts my open with time in the form of voids or cavities, which are no longer topographic objects. From all of the aforementioned cartographic materials, through vectorization, spatial layers presenting the built-up areas as well as other objects related to the mining industry were acquired. The vectorization results can be read through the described web application. As supplementary materials, elevation data presenting the Digital Terrain Model based on airborne laser scanning (Figure 6) was used. The DEM was used at the stage of preparing the field 
reconnaissance and during the initial detection of "depressions" associated with the remains of the mining industry.

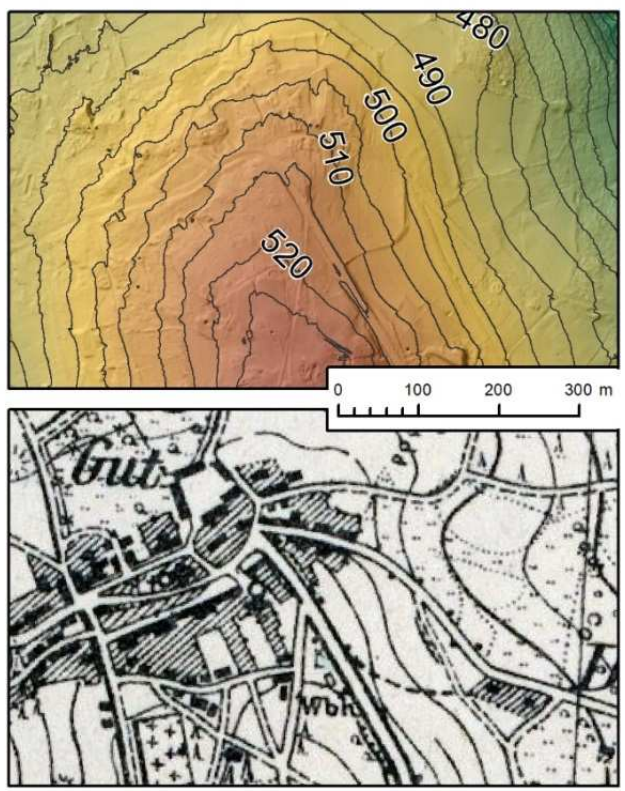

Figure 6. Contemporary Digital Terrain Model, terrain relief shown using shading (on the top), topographic map 1: 25,000 from 1939 (on the bottom). The same spatial range was used on both parts of the drawing.

Additional supporting materials used in the study were vector materials obtained from the General Geographic Object Data Base, the State Register of Borders and the State Register of Geographical Names. Objects obtained from bases were used at the stage of preparation for field reconnaissance.

\subsection{Data analysis of uranium ore mining in research area}

\subsubsection{Short history of uranium ore mining}

On the basis of the interstate agreement concluded between People's Republic of Poland and the USSR in 1945, the "Kuznieckije Rudniki" company was established on January 1, 1948, whose task was to search for and excavate uranium ore in Lower Silesia. At the beginning of 1948, the "Exploratory Group No. 1" of this company confirmed the presence of uranium ore deposits in the excavations of the former copper ore mine in Miedzianka. Therefore, the "Camp 2" was established in Miedzianka, which was identifying and excavating the uranium deposit. By the end of that year, around 236 tons of uranium ore could have been extracted. The largest amount of uranium ore was extracted in 1950 with the amount of 7601 tons. The deposits quickly depleted and in the first quarter of 1952 the uranium mine in Miedzianka was closed (Madziarz, 2010).

About $15000 \mathrm{~m}$ of excavations of the former copper mine were inventoried before the exploitation of uranium. In 1948, $8300 \mathrm{~m}$ of old excavations were rebuilt and modernized and $614 \mathrm{~m}$ new ones were hollowed out. In 1949, 12700 m new excavations were hollowed, and $17160 \mathrm{~m}$ were done in the record year 1950 . In the next year of exploitation, there were already signs of depletion of the deposit and for this reason the mining was limited - this year $9559 \mathrm{~m}$ of new excavations were drilled. In 1952 only $45 \mathrm{~m}$ of new excavations were drilled (Madziarz, 2010). It should be assumed that those excavations that were restored for use in 1948 should be vectorised on mining maps. This means that up to $8300 \mathrm{~m}$ of reactivated excavations in 1948, in 1948-1952 a hollow of $40079 \mathrm{~m}$ of new excavations was added. Unfortunately, there is no information on the type of the workings in historical materials. Exploitation and preparation works need to be plan so that after extraction of the ore is finish the liquidation process can begin (planed roof collapse or a backfill is used to hold the roof). Underground mine infrastructure includes excavation areas (most numerous), transportation, ventilation, drainage and other auxiliary excavations (less numerous since each excavation can serve some or all of mentioned functions).

In July 1952, the mine was taken over by the Polish authorities, who initially included it into the Arsenic Industry with the headquarters in Zloty Stok. Then the mine was handed over to the Sudeten Mining Plant (Madziarz, 2009). During this period, mining and geological works were continued, in order to better recognize the deposits geological structure and estimate resources - mainly of copper, arsenic and silver ore. A further $1300 \mathrm{~m}$ of new mining excavations were drilled (Madziarz, 2010). Most probably, at the turn of 1955 - 1956, the decision was made to close mining operations. This decision meant the dismantling of mining infrastructure, the elements of which were eagerly sought by other mining plants in the country. In summary, it can be stated that the old historical excavations of copper ore mines are about $6700 \mathrm{~m}$. After 1948, mining works reached a total length (new and revived excavations) about $50000 \mathrm{~m}$ of excavations.

\subsubsection{Data acquisition \& analysis}

In order to identify the course of these excavations, copies of about 80 original mining maps of the Miedzianka mine were obtained from the state resource of the Archives of Measurement and Geological Documentation kept by the State Mining Authority in Katowice, which collects the survey and geological documentation of the closed mines. They were calibrated using the location of mining shafts, then the axes of excavations of all mining levels were digitized (Krawczyk 2018). Such digitized axes were used to calculate a very approximate area and volume of excavations. It was assumed that the average width of the excavation was about $3 \mathrm{~m}$ and its height was about $2 \mathrm{~m}$. Next, the length of the excavations was calculated and the map of excavations and surface map was compiled. Table 1 presents a list of the length of excavations at individual extraction levels.

Table 1. Length of inventoried mining excavations at individual mining levels

\begin{tabular}{|c|c|c|c|}
\hline level & length $[\mathrm{m}]$ & area $\left[\mathrm{m}^{2}\right]$ & volume $\left[\mathrm{m}^{3}\right]$ \\
\hline III & 41.92 & 125.76 & 251.52 \\
\hline 46 & 182.77 & 548.30 & 1096.60 \\
\hline 56 & 333.91 & 1001.74 & 2003.47 \\
\hline 66 & 4360.01 & 13080.02 & 26160.04 \\
\hline 76 & 76.41 & 229.22 & 458.43 \\
\hline 84 & 2633.14 & 7899.41 & 15798.82 \\
\hline 96 & 3042.24 & 9126.71 & 18253.41 \\
\hline 112 & 1121.37 & 3364.10 & 6728.19 \\
\hline 138 & 2514.54 & 7543.62 & 15087.2 \\
\hline 178 & 2243.13 & 729.38 & 13458.75 \\
\hline 220 & 873.59 & 2620.78 & 5241.56 \\
\hline
\end{tabular}




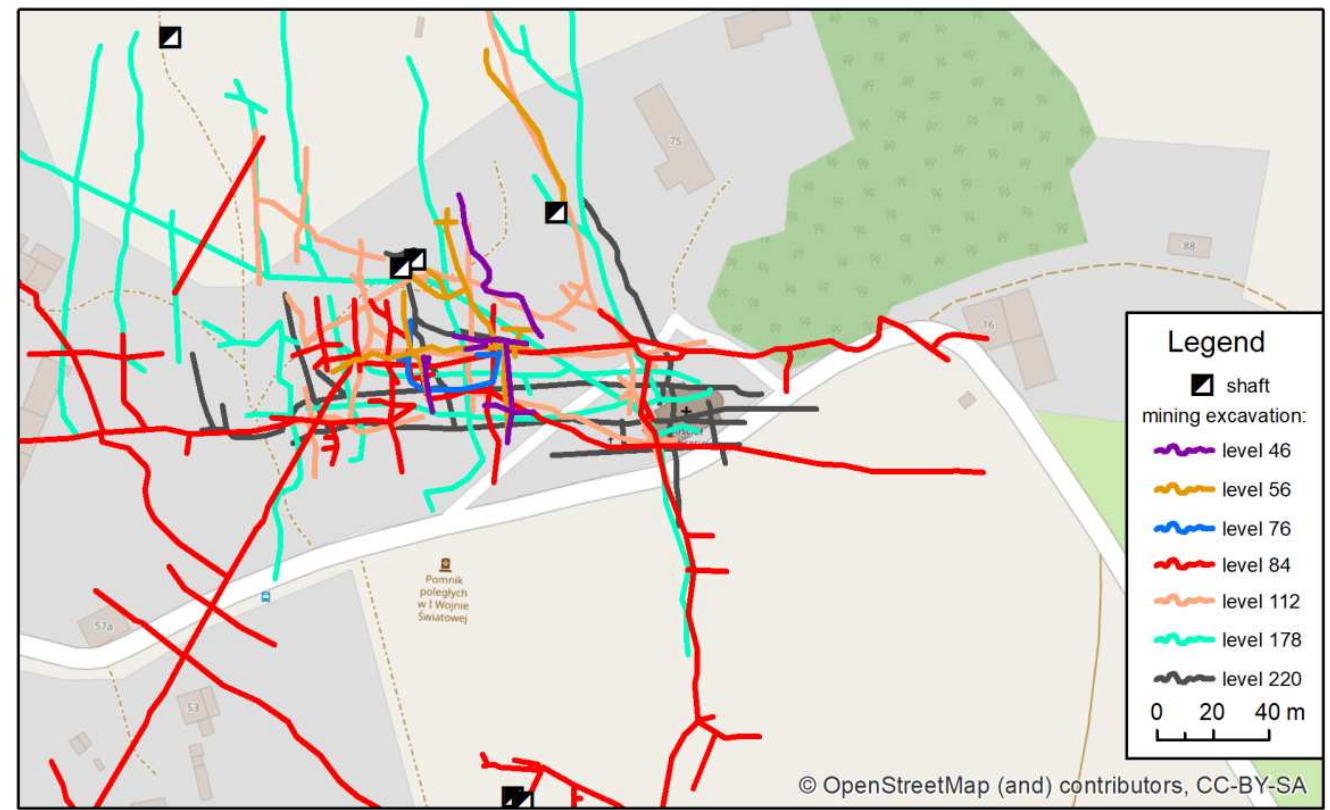

Figure 7. A network of mining excavations in the area of the Catholic Church in Miedzianka.

In total, $17423.03 \mathrm{~m}$ of current excavations were inventoried on 80 sections of mining maps. It allowed to estimate the quantity of mining spoil for over $100000 \mathrm{~m}^{3}$. Excavation density and the complexity of its formations are shown in Figure 7.

Some maps of mining excavations were made in a city called Stalinogród. It was the name bestowed upon the city of Katowice after Stalin's death from March 7, 1953 to December 12,1956 . This means that the maps had to be created as early as after 1953, at least a year after the end of uranium mining. It can be assumed that they document the condition of the mine until 1956 without further updates. This is evidenced by the unchanged name of the city in these documents. If the map was updated after 1956, the name of the city would have to be changed or supplemented. Some maps do not have information about the place of performance and are entirely in Russian. Despite the different techniques of making these maps, they all constitute a single data resource because all of these maps are included in the collective map (title card) and are degraded in the same way - all these maps have truncated corners of the map frame. Map corners were crucial in precisely fitting a given map section to the remaining neighbouring sections.

Unfortunately, there is no data on source, method and accuracy of survey data for these mining maps. It is unknown if the maps were drawn from some other older maps or simply their content has been measured and scaled down from scratch. On the maps, there are many "open" workings not terminated by the line of the face of this excavation as well as there are no signs that the excavation is outcropped to the land surface. It allowed to presume that the excavation was only partially vectorised. It is also known from the title sheet of mining maps that there are no maps for two mining levels in the resource. Unfortunately, the materials turned out to be incomplete. Comparing the estimated number of excavations made and reactivated for mining production at almost $50000 \mathrm{~m}$ with excavated excavations on mining maps $17500 \mathrm{~m}$, we obtain the scale of the problem in the form of $32500 \mathrm{~m}$ excavations of unknown location.

\section{FIELD RESEARCH}

In order to obtain and optimize data of the area, "KNGK Geoinformatyka" student research group made a field inspection in Miedzianka village. Research group included six students of University of Science and Technology and 2 lecturers. Inspection was done between $6^{\text {th }}$ and $8^{\text {th }}$ of October 2018. The works have been divided into several stages containing inventory photographs (no.1 \& no. 2) and land surveying measurements (no. 3):

1. finding remains of mining exploitation - mining shafts, outcrops of mining excavations, shaft towers, (photographs and GNSS measurements were done)

2. finding the remains of residential, service and important buildings that were landmarks: the Evangelical church, the old brewery, inn and one unidentified building (photogrammetry based inventory of facades was performed)

3. GNSS static measurements to obtain a measuring base for subsequent field interview.

Additionally, to improve field interview, the materials (archival data, DEM model) that were previously available were used. On the basis of archival maps, remains of shafts, mining excavations and shaft towers were found during the field inspection (Figure 8). Some of the shafts have been preserved in very good condition (brick shaft housing), while the remaining ones have been completely filled up. Residues of residential buildings were also retrieved, whose present state allowed to observe the post-exploitation effects (Figure 9). Another important source of data was the DEM model, which allowed to find large number of depression funnels and dislocations of the surface layer in the form of cracks and sinkholes in the field.

On the basis of PSInSAR interferometric analyses, special areas were observed that were stable (no terrain displacement occurred on it). Therefore, 5 field points on which static GNSS measurements were made have been stabilized in selected areas. 
They aimed to establish current XYZ coordinates of selected elements in the area. This will be later used as a base for further GNSS measurements that might allow to observe presumed terrain subsidence. Thus 3 GNSS points were set outside selected with mining activities maps, subsidence area and 2 were placed inside. Survey was done via GNSS Leica Viva GS16.

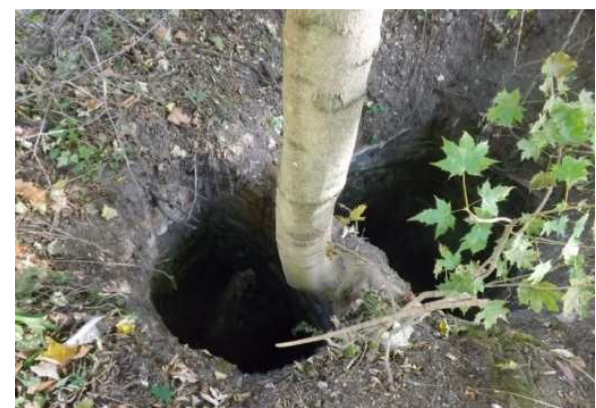

Figure 8. Remains of one of the mining shafts in Miedzianka village.

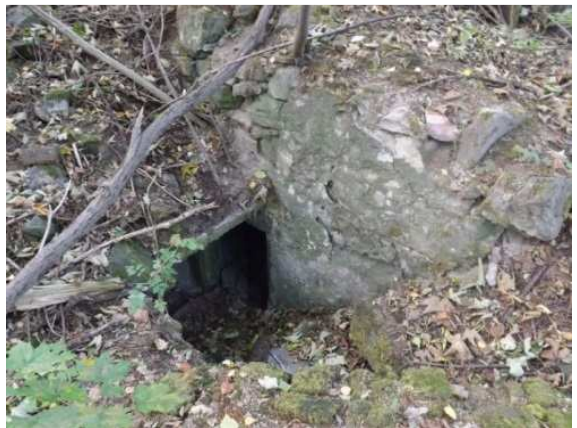

Figure 9. Residential buildings remains in the central part of Miedzianka village (near the Catholic Church).

\section{BUILDING 3D MODELS FROM PHOTOGRAPHS}

Structure-from-motion algorithms are an emerging tool of photogrammetry that allow to create 3D Mesh models, textured Mesh models and point clouds from a series of photographs. These algorithms are a relatively new part of photogrammetry. They allow for almost automatic creation of 3D Mesh models, textured Mesh models and point clouds from a series of pictures (Strach et al., 2017). Algorithms localize objects' high-contrast features, follow their movement within series of photographs and produce a sparse point cloud basing on feature placement in the image series (Ryan et al., 2015). A series of filters is used in order to lower the quality of the photographs and find most prominent features of the modelled element. In most current applications, cameras do not need to be pre-calibrated, camera calibration is done within the algorithm. Software possesses calibration information for standard camera or lens types and this data is used to remove distortion.

Agisoft Photoscan was used in this project. This software is initially basing on a traditional stereo-image analysis. Software looks through pictures in order to find matching pairs - left and right image. Basing on them, a 3D scene and a 3D location of cameras is extracted. Then another pair is added to the created model. It is mostly advised to be used with drone-based pictures and performs best in exterior modelling. However, it can be used for hand held cameras. This involves taking pictures in the way stereo images would be produced. Pictures should be taken from one or more "base lines" while moving along the front of the object. Optical axis of the camera should be at all times perpendicular or almost perpendicular to the baseline. Models do not have a proper scale. To scale the object markers, points of defined coordinates or defined size can be used. Their coordinates or size is implemented into the software by the user. For "Miedzianka" project four 3D Models (Figure 10) were created - Catholic Church, inn, brewery and an unidentified building.

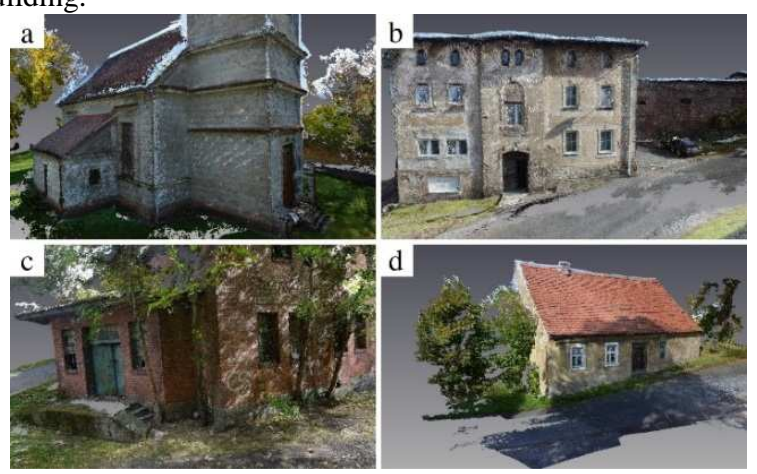

Figure 10. 3D model of a) church, b) inn, c) brewery, d) unidentified building

All of those objects are part of old town of Miedzianka and have been preserved from destruction in late $60 \mathrm{~s}$ of $20^{\text {th }}$ century when the rest of town's buildings were removed. Church and the inn are still used and remain in good condition. Brewery and unidentified building are slowly falling into decay. Only accessible parts of the objects exterior were modelled, which included 3 walls of the inn, brewery and an unidentified building. All four sides of the church were modelled. Number of pictures used: inn - 656, brewery - 354, unidentified building 153 , church -621 . Time of calculation was 8 hours for the smallest objects and 40 hours for the church (8 GB RAM and GeForce 960 GTS graphic card). In order to scale the model, 3 black and white chessboards were placed on the object. Since on-site GNSS measurement was done do establish the location of the buildings, they were georeferenced with map based coordinates. As a result, dense point clouds and 3D textured mesh model was created. Later on, four animations were produced that can be seen as links on the webpage. Links are placed in the location of the buildings on the map.

\section{WEB APPLICATION}

One of the most important aspects of the project was to publish collected data along with research results for anyone who might be interested in information on Miedzianka. The aim was also to present those data online, which would make them available to anyone using a web browser, regardless of place and time (www.miedzianka.agh.edu.pl).

All data used in the project is characterized by coordinates and some other types of attributes, Geographic Information System (GIS) allows to link that data. Data in various formats were finally selected for publishing including vector maps, photos and videos. Due to this, it was decided to use a WebGIS platform ArcGIS Online (AGOL) provided by ESRI, which allows to display photos, create multiple layers that can be turned off or turned on by the user and much more. According to (doc.arcgis.com) AGOL makes sharing content with others 
easy, thanks to user-friendly cloud-based solution. Authors decided to create web app to allow users not only to display information, but also to perform simple operations. Users can select layers to be displayed, measure the distance, search for particular address, prepare print out of current map view and draw temporary geometric objects within map window. Figure
11 presents sample printout from the application. The interactive map contains also a base map (OpenStreet Map) to help user get a reference. The application is fully responsive and compatible with any size of screen and any type of browser. Project was completed under an open academic license.

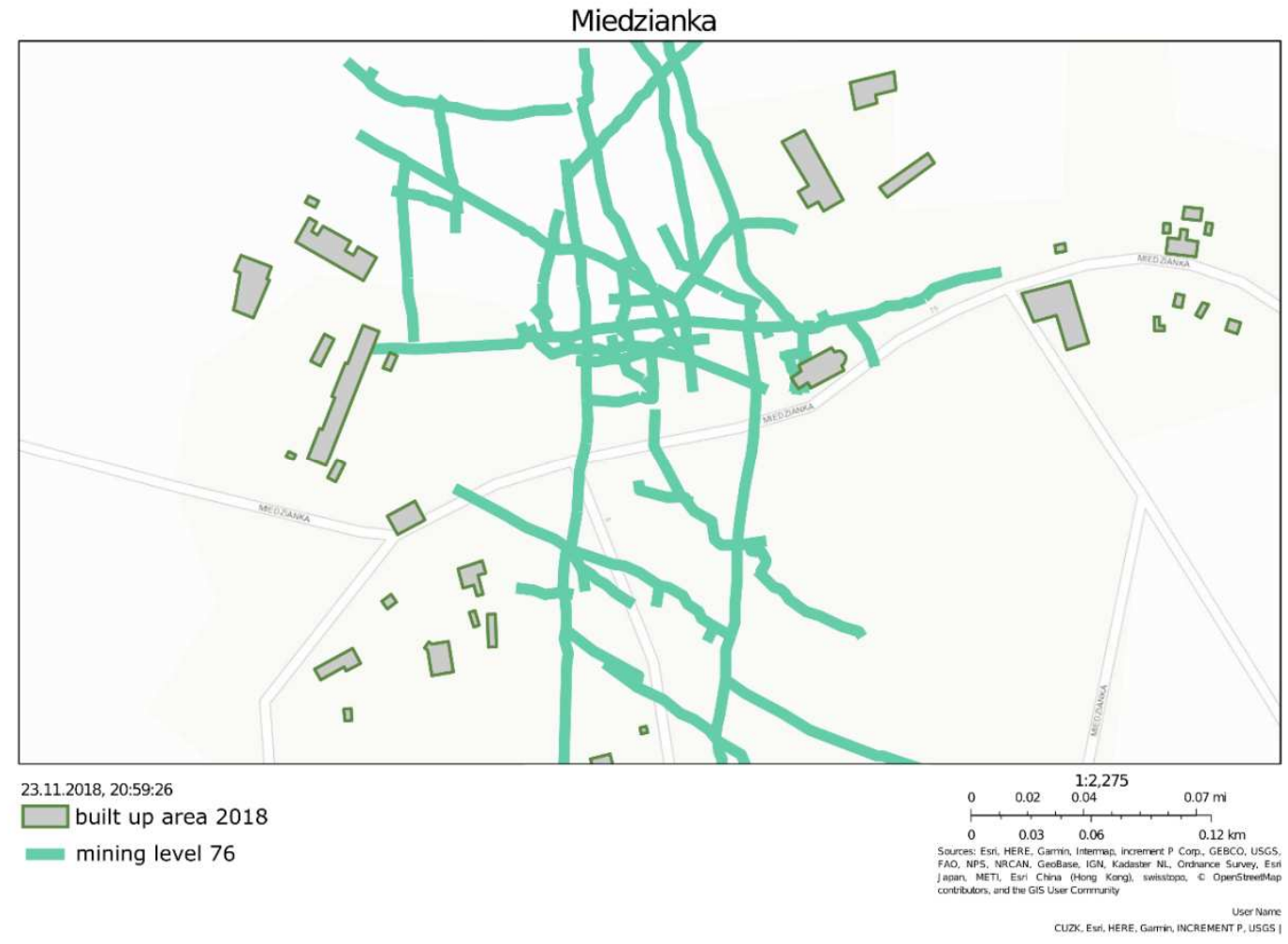

Figure 11. Sample automatic printout from the application.

The records consist of vector layers of several mine excavations including roadways, shafts and drifts, vector maps of buildings since 1886 to 2018, which allow the user to track building changes. In the future, the application will be enriched with simplified vector layers for their better visualization in scale ranges. The vectorization will be carried out with objective methods taking into account the verification of the results after generalization (Chrobak et al. 2017). Moreover, user can browse geotagged photos taken recently by project members that present current evidences of mining industry and its residues in Miedzianka, along with videos presenting models of a few buildings of Miedzianka.

Using ESRI ArcMap, the graphic layout of the map was prepared. The appropriate colours and symbols have been assigned to the geodatabase layers. Then, final map was exported to the AGOL cloud. Within AGOL content supports REST map service was created. Finally, web application configuration using WebAppBuilder was performed with emphasis on user-friendly interface. All of the functionalities are cloud-based

\section{DISCUSSION AND CONCLUSIONS}

Through described phases of the project various types of data have been collected. However, understanding and analysing them often required time, effort and specialized software, which can be unattainable for non-academicals parties. It was possible to obtain cartographic documentation that served as a base for establishing the timeline of excavation and liquidation processes. It was also possible to calculate the length of excavations on each level of the mining area. The location of shafts, most probably only those that have been active or semi active during last phases of mining activities, was possible.

During field research locations of those shafts were checked, and pictures and GNSS survey done. Also buildings and remains of buildings were localised and for some that remained in good shape 3D models were made. All digital data was stored with the use of ArcGIS and published on-line via AGOL technology. Creating an open-access web app can provide access to both historical and current records, presenting them in a friendly way. Benefits, like ease of browsing content of the app and ability to perform basic analysis only within a web browser, occur. The project has proven to be a good solution for popularizing the history of Miedzianka. Authors hope that incoming stages of research will supplement the data already available.

Further plans involve estimating the volume of excavations (basing on maps). This will allow for better planning of gravimetric research that might allow for finding and estimating the volume of underground voids. If mentioned voids would be find it will be proper to compare their volume with excavation volume. This will allow to estimate how much of the roof has fallen and how much stayed intact. It will also be necessary to 
make another GNSS survey in order to estimate if the land has subside.

It is generally assumed that during the time when last excavation in Miedzianka (uranium) was concluded the liquidation works were not done properly. The communist government at the time decided that instead of putting a lot of money and time in sealing shafts and excavations properly they would just move all the inhabitants into safer area and destroy and close the settlement. However, after all this time shafts that were not secured properly or at all are a danger to inhabitants of nearby villages and tourists. This is why it is becoming more important now to document excavations, estimate potential dangers and provide proper safety measures.

\section{ACKNOWLEDGEMENTS}

The research and application presented in this article was carried out as part of the Rector's AGH-UST Grant "Construction of an information system for permanent monitoring of land deformation caused by historical mining in Miedzianka in Lower Silesia with the use of satellite radar interferometry", implemented by a team of students from the KNGK "Geoinformatyka" Student Research Group at the Faculty of Mining Surveying and Environmental Engineering.

\section{References}

DeBruin N. M., Prescott C., L., 2005. The Maryland Coal Mine Mapping Project: Providing Access to Historic Maps for Today's Uses. World of Coal Ash Conference, Conference Papers, Lexington.

Chrobak T., Szombara S., Kozioł K., Lupa M. 2017. A method for assessing generalized data accuracy with linear object resolution verification, Geocarto International, 32:3, 238-256, DOI: $10.1080 / 10106049.2015 .1133721$.

Gomarasca M., 2009. Basic of Geomatics. Springer, pp. 10-11.

Krawczyk A., 2018. A concept for the modernization of underground mining master maps based on the enrichment of data definitions and spatial database technology. E3S Web Conf., EDP Sciences, 26(00010).

Longley P. A., Goodchild M. F., Maguire D. J., \& Rhind D. W., 2001. Geographic information systems and science. Chichester: Wiley, pp. 4-11.

Mancia, M.S., Mancia, A., 2017, Elements in the market of the real estate property in Oradea, Journal of applied engineering sciences, Volume: 7 Issue: 2 Pages: 44-47, DOI: 10.1515/jaes2017-0012.

Madziarz, M., 2009. Kopalnie „Czarnów”, „Miedzianka” $i$ „Stara Góra” w poszukiwaniach okruszcowania uranowego oraz rud metali w latach 40. i 50. XX w. in Dzieje górnictwaelement europejskiego dziedzictwa kultury t. 2 ("Czarnów", "Miedzianka" and "Stara Góra" mines in the search for uranium and metal ores in the 1940s and 1950s, in History of mining element of European cultural heritage, Volume 2), Oficyna Wydawnicza Politechniki Wrocławskiej, Wrocław, pp. 166193.
Madziarz M., 2010. „Cuprifodina in montibus” o historii $i$ pozostatościach dawnych robót górniczych $w$ rejonie miedzianki - miasta zrodzonego $i$ unicestwionego przez górnictwo w Dzieje górnictwa - element europejskiego dziedzictwa kultury, t. 3 ("Cuprifodina in montibus" about the history and remains of former mining works in the area of Miedzianka - a town born and destroyed by mining, in History of mining - element of European cultural heritage, Volume 3), Oficyna Wydawnicza Politechniki Wrocławskiej, Wrocław, pp. 258-287.

Makuch M., Stolarczyk T., 2013. Miedzianka. 700 lat dziejów górniczego miasta ( Miedzianka. 700 years of the history of the mining town's). Muzeum Miedzi w Legnicy, Legnica.

Olejnik K., 2015. Portal mapowy jako źródło informacji o terenie pogórniczym na przykładzie Zagłębia Wałbrzyskiego (Geoportal as the source of geographical information about post-mining area based on the example of the Wałbrzych Coal Basin). Hereditas Minariorum, Vol. 2, pp. 161-174.

Ryan J., Hubbard A., Box J., Todd J., Christoffersen P., Carr R., Holt T. O., Snooke N., 2015. UAV photogrammetry and structure from motion to assess calving dynamics at Store Glacier, a large outlet draining the Greenland ice sheet, The Cryosphere, 9, 1-11.

Springer F., 2011. Miedzianka. Historia znikania. (Miedzianka. History of disappearance). Czarne.

Szmytkie R., Krzysztofik R., Dymitrow M., Kantor-Pietraga I., Pełka-Gościniak J., Spórna T., Brauer R., 2015. Miasta zdegradowane a procesy opustoszania (Degraded towns and urban abandonment). University of Gothenburg, pp. 198-200.

Staffa M., 1998. Rudawy Janowickie, Stownik Geografii Turystycznej Sudetów, tom 5 (Rudawy Janowickie, Dictionary of the touristic geography of the Sudety mountains, volume 5) IBIS, Wrocław.

Strach M., Tama A., Lewińska P., 2017 Comparative Analysis of 3D Models Made with Various Technologies on the Example of Altar in the Wang Temple in Karpacz, 2017 Baltic Geodetic Congress (BGC Geomatics), Gdansk, 2017, pp. 116-120. doi: 10.1109/BGC.Geomatics.2017.17.

Tama A., Adamek K., Pargieła K., Ochałek A., Krawczyk A., Lupa M., 2018. Monitoring of historical land use changes caused by underground mining in Miedzianka town, based on a webgis tool and InSAR observations, Journal of Civil Engineering, Environment and Architecture, 65(1), pp. 127140. DOI: $10.7862 / \mathrm{rb} .2018 .14$

Zimnoch E., 1978. Mineralizacja kruszcowa złoża Miedzianka w Sudetach (Mineralisation of the Miedzianka deposit in the Sudety Mountains), Biuletyn Instytutu Geologicznego, 308(1), pp. 91-134.

\section{Websites}

Demographic data for Miedzianka village for years 2002-2011, bdl.stat.gov.pl (view at 12 Nov. 2018).

What is ArcGIS Online? https://doc.arcgis.com/en/arcgisonline/reference/what-is-agol.htm (view at 10 Nov. 2018). 